\title{
Implementation of Bela Negara Values to Develop a Good Public Service
}

\author{
Dr. Herlina Juni Risma Saragih, M.Si, Shinta Rayana Kartika Putri, S.IAN, and Aryo Cahyo \\ Kusuma Wardana, S.Sos \\ Indonesia Defense University, Sentul, Indonesia \\ herlinsara897@gmail.com; shintarkp@gmail.com; aryo.ckwardana@gmail.com
}

\begin{abstract}
Bela Negara is a program developed by the Ministry of Defense as an actualization of Pancasila, the 1945 Constitution and the Unitary State of Republic Indonesia. It should be implemented not only pragmatically but also professionally in daily basis, such as public servant activities. In case of public services, the main problem is related to the quality of service itself which is felt by the society is still low, because in its implementation still has many weaknesses. The situation shows that public service urgently needed to be improved, as a form of Bela Negara efforts to create clean government, better service for the community. Based on that, this paper aims to illustrate that one of the way to implement Bela Negara values can be done by providing a good public service. This paper used a qualitative descriptive method. The Data is obtained through interviews and further documentation studies. The subjects of this study are the Head of Provincial Employment Agency of DKI Jakarta, and Secretary of Human Resources Development Agency of DKI Jakarta. The results from descriptive analysis shows that to restore discipline, morals, and develop a good service, it is necessary to form a training that could put forward the insight of nationality, to develop a service that could fulfil the community needs. The main purpose is to socialized and internalized the Bela Negara Awareness Program and its values in their respective environments as the base of attitude and behavior of state servants.
\end{abstract}

Keywords: Bela Negara, Public Service, Public Administration, Good Governance

\section{Introduction}

Bela Negara is a program developed by the Ministry of Defense to build and strengthen national awareness for the citizen. Bela Negara is the actualization of Pancasila, the 1945 Constitution and the Unitary State of Republic Indonesia, it is one of the rights and obligations of all Indonesians. The 1945 Constitution also provides the Bela Negara mandate as referred in Article 27 paragraph (3) "Every citizen shall have the right and obligation to participate in the defense of the state". The Bela Negara measures are defined in Article 9 paragraph (2) of Law No. 3 of 2002 on Bela Negara which states that. "Citizen participation in Bela Negara can be done through civic education, military training, military and military base volunteering and devoting themselves to defend the country and its people".

Bela Negara is the effort of every citizen to defend the country against the threats both from within and from within the country. Meanwhile, the state is the determination, attitudes and actions of citizens are well organized, comprehensive, integrated and sustainable based on love of the homeland, awareness of nation and state, the belief in Pancasila ideology as the National Ideology. Bela Negara is essentially a comprehensive, integrated and sustainable determination, attitude and action based on the love of the country, the awareness of Indonesian nation and state and the sacrificial belief to eliminate the threat, both from outside and from 
within the country. countries that endanger the independence and sovereignty of the state, the unity and unity of the nation, territorial integrity, and national jurisdiction and the values of Pancasila and the 1945 Constitution.

In the Basic Book of Bela Negara published by the Directorate General of Defense Potential in 2014, is also included on the implementation of state defenses and indicators of successful state defense awareness in the work environment. Activities undertaken include: planned activities in the environment, additional activities that support the morale, activities related to corporate social responsibility / office, and the creation of conducive working conditions. However, actual state defending is hampered and constrained by the existence of a group of people with contradictory ideas that will contradict with the values of nationalism, patriotism and love of the homeland, as well as a society that is always concerned with private, group, party and party interests, without regard to and prioritizing the interests of the nation, the state, and society. The spirit of willingness to sacrifice, abstinence, fighting and patriotism have been displaced by the values of individualism, consumerism, hedonism, and bourgeoisie that lead to a moral crisis. This understanding provides an opportunity that extends to every citizen to conduct state defending activities. The values contained in the state defense are:

1. Love to the homeland:
a. Maintain the land and yard and the entire space of Indonesia
b. Soul and body as a nation of Indonesia
c. Has a patriotism to the nation and state
d. Keep the good name of the nation and country
e. Contributing to the progress of nation and state

2. Awareness of nation and state

a. Participate in public, professional and political organizations.

b. Conduct rights and obligations as citizens in accordance with applicable legislation.

c. Participate in elections.

d. Thinking, acting, and doing the best for the nation and the State

e. Participate in keeping the nations and nations alive

3. Believe in Pancasila as the State Ideology:

a. Understanding the values in Pancasila.

b. Practicing the values of pancasila in everyday life

c. Making Pancasila a unifying nation and country.

d. Always develop Pancasila values.

e. Be confident and believe that pancasila as the basis of the state.

4. Willingness to sacrifice for nation and country:

a. Willing to sacrifice his time, energy and mind for the progress of nation and state.

b. Ready to defend the nation and state from various threats

c. Participate actively in the development of society, nation and state. 
d. Be confident and believe that sacrifices for the nation and country are not in vain.

5. Have Physical and Psychic Preparedness:
a. Have an emotional and spiritual intelligence.
b. Always nourish the soul and body
c. Always give thanks and pray for the pleasures God has given me.
d. Love to exercise
e. Always maintain health.

Bela Negara is the right and duty of every citizen, therefore Bela Negara is very important to be submitted in every citizen. Bela Negara should not only take the form of pragmatic national activities, but also professional activities in everyday life, such as public servants activities. One of the strategic ways to cultivate Bela Negara values in every activities is through education. Education is a process to improve the quality of human resources in the life of society, nation and state.

In case of public services such as in the DKI Jakarta Provincial Government, mostly the main problem is related to the quality of service itself which is felt by the society is still low, because in its implementation still has weaknesses, less responsive, less informative, less accessible and less coordinated, making it difficult for people who need services, frequent overlaps between the policies of one agency and another service agency, as well as a long and inefficient bureaucracy. This problems that usually occurs in the Government is the opposite of the value of Bela Negara, since one of Bela Negara value is Willingness to Sacrifice for Nation and Country which demand all of the citizens including public servant to sacrifice by prioritizing the public interest rather than personal interest.

Therefore, in order to create clean government, and increasing public service and sense of justice in society. condition shows that there is no indication of increasing the law enforcement efforts and public service still need to be improved again, as a form of Bela Negara efforts

\section{Research Aims}

Since public service is an activity in the framework to fulfill the needs of services in accordance with legislation for every citizen, services and / or administrative services provided by public servants (Law No. 25 Year 2009 on Public Service). It is necessary to improve the public services of DKI Jakarta Provincial Government through comprehensive improvement covering the aspects of institutional, human resources, management and accountability, which is expected to produce an excellent public service that is fast, accurate, cheap, safe, fair and accountable.

Because, public service is also the main foundation in improving welfare to society. In terms of aspects of human resource development, more education and training, such as Provision of Bela Negara Values are needed in order to increase the knowledge and skills of employees to be able to provide better public services, and also to serve wholeheartedly. By realizing good and efficient public service through implementation of Bela Negara Values in DKI Jakarta Provincial Government, it is believed that it can simplify the citizen of DKI Jakarta to fulfill it needs. For that, this paper aims to shows whether the values of Bela Negara had 
been implemented by DKI Jakarta Provincial Government in order to provides the best service for the community or not.

\section{Literature Review}

\section{Civil State Apparatus Concept}

In article 1 number 1 of Law no. 5 year 2014 which states that the Civil State Apparatus (ASN) is a profession for Civil Servants (PNS) and Government Employees with Work Agreement (PPPK), which works on government agencies. The civil servant according to the Indonesian General Dictionary, is the person who works for the government or the state. According to Kranenburg the Civil Servant is a designated official, so that understanding does not include those holding positions such as members of parliament, and the president.

Based on some definitions it can be concluded that civil servants are people who work in the environment government agencies in accordance with certain conditions set by the legislation. In accordance with Law no. 5 years 2014.

In implementing legislation in general, ASN employees are given the official duty to be implemented as good as possible. As a state servant ASN employee also must be loyal and obedient to Pancasila as the philosophy and ideology of the state, to the 1945 Constitution, to the state, and to the government. ASN employees as an element of the state apparatus, state servants and public servants are required to perform their duties properly, therefore he must have loyalty, full adherence to Pancasila, 1945 Constitution, state and government so as to focus all attention and mind and direct all power and effort to carry out government and development tasks in a versatile and effective manner.

\section{Organization Culture Concept}

Organization is a group that gathers members who have a particular purpose and work together to achieve the objectives that have been set in which the group has a structure that contains units of work as a grouping of tasks or jobs of the kind from the easiest to the hardest where each unit have volume and workload that must be realized in order to achieve organizational goals. In the achievement of these objectives required coordination in the implementation of cooperation based on a procedure that has been formally organized.

According to Davis in Lako, organizational culture is a pattern of beliefs and organizational values that are understood, imbued and practiced by the organization so that the pattern gives its own meaning and the basis of rules of conduct in the organization. The same is also expressed by Mangkunegara which states that organizational culture is a set of assumptions or belief systems, values, and norms developed within the organization that serve as a behavioral guideline for its members to address external and internal adaptation issues. According to Stephen P. Robbins in his book Organizational Behavior divide the five functions of organizational culture, as follows:

1. Role to set limits.

2. Delivering a sense of identity for members of the organization.

3. Facilitate the emergence of a wider commitment than one's individual interests.

4. Improving the stability of the social system because it is a social glue that helps unify the organization. 
5. As a control and a rational mechanism that guides and shapes attitudes and behaviors of employees.

Thus, it can be concluded that organizational culture is a pattern of beliefs and organizational values that are believed and imbued by all its members in doing the job as a proper way to understand, think and feel on related issues, so that will become a value or rules in in the organization. It clearly shows how the quality of service provided by the state apparatus is actually inseparable from the internal behavior of bureaucrats or civil servants themselves.

\section{Good Governance Concept}

Good governance concept is the process of organizing state power in implementing the provision of public goods and services, while the best practice is called good governance, the form of good governance is the commitment of all parties, namely government and society.

The main objective of good governance is to achieve a governmental condition that can ensure the interests of public services in a balanced manner by involving cooperation among all parties or stakeholders (state, civil society and private sector).

Based on the above description, it can be concluded that Good Governance is a governing process that combining the use of economic, political, and administrative authority to manage the State affairs at all levels. Governance includes all mechanisms, processes and institutions where citizens and community groups express their interests.

\section{Research Method}

This paper uses descriptive research methodology with qualitative approach because the data that obtained from the research is a written word or speech gathered from the results of interviews with informants or direct observations in the field. In other words, various data in the implementation of cultivating the values of Bela Negara by Civil Servants in the Jakarta Provincial Government are more in the form of words and sentences or language, so it is more appropriate to use a qualitative approach to examine it. Using a qualitative descriptive method, the authors want to see the point of view from someone who has relevance to the background of this research that is relevant informants supported by some data. Therefore, the subjects of this study are The Head of Provincial Employment Agency of DKI Jakarta, and Secretary of Human Resources Development Agency of DKI Jakarta.

\section{Discussions}

The result of interpretation of data obtained through observation on understanding, attitude and Bela Negara behaviors of Civil Servant of DKI Jakarta Provincial Government, in the following sub-section, the researcher will discuss sequentially starting from the Civil Servant of DKI Jakarta Provincial Government as reserve component, the implementation of Bela Negara Values through understanding, and last is the Civil Servant of DKI Jakarta Provincial Government service quality in order to create Good Governance that is reviewed from the theory. 


\section{Civil Servant of DKI Jakarta Provincial Government Understanding of Bela Negara Values}

Understanding of Bela Negara Values is very necessary in Jakarta Provincial Government, because it could create discipline attitude in work and in public service for society, which is a reflection of Bela Negara Values so that civil servants will also defend and maintain good name of the provincial government, while providing the best services that they could give. It can be referred as in loving and maintaining the in tegrity of the Unitary State of the Republic of Indonesia where the correlation of understanding Bela Negara Values is reflected by the attitude and behavior of the civil servants through the ceremonial activities every August 17 and the annual assembly on Bela Negara's Day. Understanding of Bela Negara Values on civil servants of DKI Jakarta Provincial Government is implemented through the service provided by civil servant to the public wholeheartedly to help the people of DKI Jakarta who need their services.

\section{Implementation of Bela Negara Values Through yhe DKI Jakarta Provincial Government Organization Culture to Create Good Governance}

In implementing the Bela Negara Values as well as providing services to the public, DKI Jakarta Provincial Government has an integrated service form called "Pelayanan Terpadu Satu Pintu" (PTSP) a One-Stop Integrated Services that located in every urban village and sub-district in DKI Jakarta, especially for the DKI Jakarta Central Government itself PTSP is concentrated in a special facility called "Mall Pelayanan Publik" (Public Service Mall), it is a 14 story integrated services facilities made by DKI Jakarta Provincial Government in cooperation with various agencies that could provide various public services under one roof. In these facilities, there are 328 types of services, 296 come from the Provincial Government of DKI, 32 others from seven ministries and state agencies. Three of the fourteen floors functioned as public service spaces, while the fourth to 12th floors were used as back office of some of these agencies.

The facilities within the Mall Pelayanan Publik building are very complete. With a slick interior design, Jakarta citizens are expected to be more comfortable while completing various kinds of public services. The service tables are neatly arranged with a number of officers who are ready to provide various services and information. They can help Jakarta citizens to complete the various tasks in accordance with their respective duties. In providing services to the public, the DKI Jakarta Provincial Government has a unique organization culture values calles "SETIA", it is consisted from five values that should be implemented by all of the Civil Servants of DKI Jakarta Provincial Government in order to give a maximum service, the SETIA values described as follows:

1. Solution (Solusi), The way or way used to solve or solve the problem objectively without any pressure.

2. Empathy (Empati), A mental state that makes a person feel or identify himself in the same state of feeling or mind with other people or groups. 
3. Decisive (Tegas), A courageous and confident attitude in making decisions and can reveal what is right and what is wrong clearly, real and definite (not vague, no hesitation)

4. Innovation (Inovasi), A creative process for turning opportunities into ideas, ideas, methods or tools that can be implemented.

5. Reliably (Andal), A high integrity, master the material that includes structure, concepts and science mindset to support daily routine.

The organization values and culture set by DKI Jakarta Provincial Government have been implemented in the daily activities of public services in DKI Jakarta Provincial Government. The criteria for each of the organizational culture values are as follows:

1. Solution, the value of this solution is implemented by the officer by being an officer capable of:

- Informs the time taken to solve the problem.

- Follow up and monitor problem solving.

- Inform problem solving result.

- Conducting persuasive communication and problem-solving alternatives if the solution is not in line with community expectations.

- Provide certainty regarding the requirements of procedures and licensing fees

2. Empathy, the value of empathy is implemented by the officer by becoming an officer who is able to:

- To feel the difficulties of the public, for example if there are citizen that have come all the way but in the processes there is still a lack of minor files, did not necessarily reject the file but still receive the file and giving notes for the applicant to complete the shortcomings data at the time of taking the permit.

- Be able to control the emotions of themselves, as we know in serving the citizens of Jakarta with various characters, an officer must be able to control his emotions and still provide friendly service.

- Prioritize the priorities (elderly, disabled and pregnant women) in providing services.

3. Decisive, the value of decisive is implemented by the officer by becoming an officer who is able to

- Make an informed decision on the basis of existing procedures

- Be honest in telling the truth

- Responsible in words and actions

- High confidence in conveying information

- Never let a problem without a decision

4. Innovation, the value of this innovation is implemented by the officer by becoming an officer who is able to

- Always focus for the future

- Love change and keep trying to make improvements (improvement).

- Not just talk but manifest in real action 
- Dare to take measurable risks

5. Reliably, this Reliable Value is implemented by an officer by becoming an officer capable of:

- Have high integrity to do the right thing

- Always develop yourself to learn and grow

- Able to establish good relationships with all stakeholders involved

- Have positive behavior and run consistently

- Mastering basic and advanced competencies related to licensing

When viewed from the Definition of Bela Negara related to the basic elements of Bela Negara, referring to the 1945 Basic Law and every citizen's behavior based on Bela Negara refers to the following elements: (1) love the homeland; (2) awareness of nation and state; (3) convinced of Pancasila as the state ideology; (4) willing to sacrifice for the nation and state; (5) has the ability to defend the country first. Then the implementation of SETIA as DKI Jakarta Provincial Government Organization Culture has indirectly covered the values of Bela Negara on the civil servants of the Provincial Government of DKI Jakarta through the involvement of civil servants in Public Service activities such as facilitating all public service process and serving the people of DKI Jakarta as well as possible. Some implementation of the organizational culture values of DKI Jakarta Provincial Government that describes the values of Bela Negara are as follows:

1. Opening the services of 518 types of licensing and non-licensing on all DPM and PTSP outlets spread over 316 service points from Provincial level up to Kelurahan. This activity is an implementation of the value of solutions and empathy and also an implementation of bela negara values of Love the Homeland.

2. Create and post posters about service requirements, time of service, and cost in each one-stop service integrated outlet this is the implementation of the cultural value Solutions and also an implementation of bela negara values of Love the Homeland.

3. The implementation of One Day Service and Drive Thru licensing, this is a form of public service innovation with the aim of cutting licensing time. This activity is an implementation of the value of innovation and empathy.

4. Transfer of License by motorcycle (AJIB), one of the leading innovations of DKI Jakarta Provincial Government is the formation of a team that assigned to pick up and deliver permission whom submitted by the applicant for free.

All of the activities and innovations above are some the implementation of organizational culture values of DKI Jakarta Provincial Government SETIA which are Solutions, Empathy, Decisive, Innovation \& Reliable. It is also a form of several implementation of the Bela Negara values. Implementation of the organizational culture value and Bela Negara values is aimed to achieve the vision of DKI Jakarta Provincial Government in conducting revolution of licensing in DKI Jakarta "Solusi Perizinan Jakarta", and the obligation realization of DKI Jakarta Provincial Government employees as reserve component, which aims to carry out the satisfaction 
of public service in DKI Jakarta and generally aims to change the bad paradigm that has been attached to the civil servants of the DKI Jakarta Provincial Government.

The organizational culture value of DKI Jakarta Provincial Government, SETIA, was introduced since the end of 2016 and set in 2017 through the Decree of the Head of Integrated Service and Investment Service Number 22 Year 2017. From January to March 2017, the Provincial Government of DKI Jakarta conducted an internal survey by using telephone to the people who have used the services of the DKI Jakarta Provincial Government, with the number of respondents as many as 936 people. The survey results show an increase in public satisfaction from $82.3 \%$ in the period of October to December 2016 to $94.74 \%$ in the period January to March 2017. With details of the lowest value aspects is the Response of "Quick Response Team" and the highest aspect is the "Service Fairness Fee". The result of this survey shows that the organizational culture value of SETIA has an effect on the level of public satisfaction which means also the increasing performance of the DKI Jakarta Provincial Government employees after applying the organizational culture values and this is in accordance with the results of the research that has been done before.

\section{Conclusions}

From the results of descriptive analysis in the discussion above, it can be concluded that:

1. Based on the results of previous research states that the value of organizational culture if it can be understood and implemented really can affect the performance improvement of the officers who implement it.

2. Implementation of organization culture values in DKI Jakarta Provincial Government if implemented properly, not only could improve the performance of employees but also have an impact on increasing public satisfaction. This can be seen with the results of internal surveys conducted by the Provincial Government of DKI Jakarta which experienced an increase in public satisfaction with an increase of $12.44 \%$ from the previous period.

3. To increase the level of discipline, morals, and good service, the DKI Jakarta Provincial Government could form a training that put forward the insight of nationality, and discipline to form a service oriented to the needs of the citizen of DKI Jakarta. In the office environment related to public services, the values of Bela Negara are required for the apparatus/bureaucrats/Institution, Local Government, BUMN employees and others. With the aim that the awareness Bela Negara can be socialized and internalized in their respective environments, so that the values of Bela Negara become the basis of attitude and behavior in everyday life. To that end, instilling the values of Bela Negara for the government apparatus is necessary for the creation of professional apparatus resources, character and love for the state that can provide good public services.

\section{References}

Basrie. (1998). Bela negara implementation and development. Jakarta: UI Press. 
Sedarmayanti. (2012). Good Governance "Kepemerintahan yang Baik. Bagian Kedua Edisi Revisi. CV Mandar Maju. Bandung.

Winarno. (2012). The new paradigm of civic education. Jakarta: PT Bumi aksara.

Ministry of Defense RI. (2014). "The basic state defenses". Jakarta: Directorate General of Defense Potential 2014

Creswell, J. W. (2010). Research Design: Pendekatan Kualitatif, Kuantitatif, dan Mixed. Yogyakarta: PT Pustaka Pelajar.

Undang Undang Republik Indonesia. Nomor 25 Tahun 2009. Tentang Pelayanan Publik

Ekowati, Lilik Roro Mas. (2009). Perencanaan, Implementasi dan Evaluasi Kebijakan atau Program (Suatu Kajian Teoritis dan Praktis). Surakarta: Pustaka Cakra.

Lako, Andreas. (2004). Kepemimpinan dan Kinerja Organisasi Isu Teori dan Solusi. Yogyakarta: Amara Books

Mangkunegara, Anwar Prabu. (2005). Perilaku dan Budaya Organisasi. Bandung: PT. Rafika Aditama 